\title{
clinical trial of Indomethacin Gel (Idomethine kowa Gel)on Rheumatoid arthritis
}

\author{
イドメシンコーワゲルの慢性関節リウマチ \\ に対する臨床試験
}

\section{drug evaluation 炎}

塩川優一・阿部重人・青木虎吉

井上幸雄・田川 宏・土方浩美

豊島弘道・菅原幸子・景山孝正

吉沢久嘉・水島 裕・菅野卓郎

入交昭一郎
慢性関節リウマチ治療の原則によると, すず一般療法 がすべての患者に行われるべきであり，そのうえで薬物 療法を行ら。

薬物療法は原則として非ステロイド剂から始め, もし 非ステロイド剂のみで不十分のときは非ステロイド剤に なんらかの特殊抗リウマチ薬を併用する。塩川の調查 ${ }^{12}$ や, 水島の調査 ${ }^{2}$, 輿石の調査 ${ }^{3)}$ によれば, 慢性関節リ ウマチ患者に対し, 非ステロイド剂, 特にインドメタシ ンおよび金製剤の投与が増加し，1979年の輿石の調査 ${ }^{3)}$ では抗りウマチ薬の使用頻度の第 1 位はインドメタシン で，400施設の $92 \%$ で使用されている.

インドメタシンは輿石の調査でわかるとおり，抗りウ マチ薬として広く用いられており, その有効性が確認さ れている，その反面，頭痛，胃腸障害などの副作用が認 められている.

このような有効な薬を局所適用により, 消化管を経 ず, 十分薬効のある濃度で局所病変組織に到達させる ${ }^{4,5)}$ ことにより, 全身的な副作用もなく, 安全にその効果が 期待されるが, イドメシンコーワゲルはこのような特徵 を有する薬剤でインドメタシンを $1 \%$ 含有するゲル状軟 膏 (ID ゲル) である.

基礎実験においても ID ゲルの塗布によりアジュバ ント関節炎治療 ${ }^{6,7)}$, カラゲニン足浮腫抑制 ${ }^{6,7)}$, cotton pellet の肉芽腫形成抑制作用 ${ }^{6)}$, 肉芽囊形成抑制作用 ${ }^{8)}$, 紫外線紅斑抑制作用 ${ }^{6)}$, Randall \& Selitto の炎症足圧

\section{本攔の担当者}

塩川優一・阿部重人：順天堂大学医学部内科学教室

青木虎吉 : 順天堂大学医学部整形外科学教室

井上幸雄 : 順天堂伊豆長岡病院整形外科

田川 宏・土方浩美 - 豊島弘道 : 東京女子医科大学整 形外科学教室

菅原幸子：東京女子医科大学第二病院整形外科

景山孝正：国立相模原病院整形外科

吉沢久嘉：国立相模原病院内科

水島 裕: 聖マリアンナ医科大学第一内科学教室

菅野卓郎：川崎市立川崎病院整形外科

入交昭一郎：川崎市立川崎病院内科

論文執筆者：阿部重人
痛抑制作用6,7) の動物実験の炎症モデルで優れた消炎, 鎮痛効果が示されている.

臨床的にも整形外科領域に括ける各種の炎症性, 疼痛 性疾患に対する諸家の報告 ${ }^{9-11)}$ があり，有効性について は高く評価されている。

慢性関節リウマチに対しては今まで報告が医とんどな いが12-14), その有効性は十分期待され，さらに安全性の 面でも心配がなく，外用であるため使用が軽便であるな ど, 一般療法と同様に薬物の基礎療法として有用性が期 待されている.

今回われわれは慢性関節リウマチの個々の関節の症状 に対する効果を検討する目的で一般臨床試験を実施し， 少数例にイドメシンコーワゲル基剤（ID ゲル基剂） と の比較を行った。な括本試験は表記の多施設共同で昭和 56 年 1 月より昭和 56 年 6 月までの 6 カ月間であった.

\section{方 法}

(1) 対象疾患

慢性関節リウマチで明らかな活動性を有し, 症状があ まり変化なく持続しているもので以下の基準に合うも の.

\section{[選択基準]}

同一基礎療法を 2 週以上続けている症例で手指の小関 節を中心に明らかな症状のあるもの（疼痛, 腫脹などの あるもの).

なお下記の項目に該当する患者は本試験の対象から除 外することとした。（1)皮膚創を有する症例，(2) 皮虐状 態の悪い症例，(3) 特に皮膚の過敏な症例（過去に外用剂 で皮膚炎を生じたことのある症例)，(4) その他担当医が 本試験に組み入れることを不適当と判断した症例.

（2）薬剂，投与方法および併用療法

(1) 薬剂，投与方法

選択基準に合致する基礎療法を行っているものは, そ の内容を変更することなく試験薬剤を投与する.

薬剤: ID ゲル。

本剂は $1 \mathrm{~g}$ 中にインドメタシン $10 \mathrm{mg}$ を含有するゼ リー状軟膏である。 
用法：ID ゲルを1日 4 〜 回患部に十分塗擦する. 塗擦直後は水洗いをしないよらにし，水洗いをした場合 はそのつど塗擦する。な拉，できれば一部に ID ゲル基 剂（基剤のみを含有）を比較できる他の部分に同様に塗 擦する。

投与期間： 4 週間.

(2) 併用療法

薬剂, 理学療法とも新たな併用は行わない.やむをえ ず併用した場合は，その内容を明記するとともに，その 理由, 経過をコメントする.

なお，金剂，D-ペニシラミンの場合は使用開始より 3 力月以上経過し, 維持量に達し, またステロイドの場 合は 1 日プレドニゾロン換算值として $5 \mathrm{mg}$ 以下の継続 投与中のものはそのまま併用をする。

（3）評価時期，評価項目および評価基準

(1) 評価時期

ID ゲル投与開始日， 2 週後，4 週後の 3 回とする.

副作用発現例, 臨床検査值の異常例については上記期 間にかかわらず消失するまで追跡調査する.

(2) 評価方法

(a) 本剂は局所用剤であるため, ID ゲル塗擦部位につ いてのみの効果を判断する. (b) 対象部位が複数の場合 は，できれば一部に ID ゲル基剤を用いて ID ゲルの効 果と比較する。(C)評価は相対的評価であるため, 同一症 例は同一担当医が評価する. (4) 途中中止例は中止時点で 評価を行ら。

(3) 評価項目および評価基準

[症状程度]

(a) 疼痛症状 (自発痛, 压痛, 運動痛), 局所熱感, 腫脹, 運動制限は症状の程度で, 高度(H), 中等度 (H), 軽度 $(+)$, 症状なし $($ 一), の 4 段階で評価する。さらに 初回塗擦時の痛みの程度を時間の経過を追って visual analogue scale で評価する。

(b) 握力（手指，手関節の場合）(水銀圧力計法）は右 または左 3 回ずつ測定し，その最高值を記入する.

(c) 概括重症度は評価対象関節の症状の程度で, 高度 $($ H), 中等度 $(H)$, 軽度 $(+)$, 症状なし $(-)$, の 4 段階 で評価する。

[改善度]

(a) 患者の評価は投与前と比較して患者の印象を問診 により，非常によくなったよくなった，変わらない， 悪くなった，の 4 段階で評価する。

(b) 医師の評価は投与前の概括重症度を基準にして, 著明改善, 中等度改善, 軽度改善, 不変, 要化の 5 段階 で評価する。

[有効性]

医師が本剂に関しての有効性を客観的に，著効，有 効, やや有効, 無効, の 4 段階で評価する.
表 1 評価症例数

\begin{tabular}{|c|c|}
\hline & 例 \\
\hline 副作用のため中止 & 2 \\
\hline 2 週で無効のため中止 & 8 \\
\hline 4 週目久測のため 2 週目で判定 & 4 \\
\hline 2 週目欠測 & 12 \\
\hline 完 全 症 例 & 107 \\
\hline 計 & 133 \\
\hline
\end{tabular}

[安全性]

(a) 副作用はその種類, 程度および経過を考慮して， 副作用なし, 軽度の副作用, 中等度の副作用, 高度の副 作用，の 4 段階で評価する。

(b) 臨㦿検査は必要に応じ, 試験開始前と終了時の 2 回実施する。

血液一般検查: 赤血球数, 白血球数, ヘモグロビン, 血小板数

血清生化学検查 : GOT, GPT, Al-P, BUN

尿検查: 蛋白, 糖, ウロビリノーゲン

その他：赤沈 $(\mathrm{mm} / \mathrm{hr})$ (Westergren 法)

[有用性]

有効性と安全性などを総合的に考慮して, きわめて有 用, 有用, やや有用, 有用とは思われない, の 4 段階で 評価する。

\section{結 果}

(1) 対象症例

評価対象症例は昭和56年 1 月より56年 6 月までに当試 験参加施設に来院した慢性関節りウマチ患者で 133 例で あった（表 1 ）。評価症例133例の内訳は, 副作用の発現 のため中止，無効のため 2 週で中止の例が，それぞれ 2 例之 8 例。 4 週目欠測のため 2 週目で判定, 2 週目欠測 で 4 週目のみ判定例は，それぞれ 4 例，12例で，完全症 例は 107 例であった。

評価症例の背景は表 2 に示すように, 性別は男15例, 女118例，年齢は19～78歳で平均年㯝は50.7歳であった。 投与前概括重症度は高度 8 例, 中等度 81 例, 軽度64例で, 軽度, 中等度が多かった。罹病期間は 6 力月未潇 2 例, 1 年末満 6 例, 3 年未満 18 例, 10 年末満 64 例, 10 年以上 42 例, 不明 1 例で, 平均 7 年 6 カ月であった。評価部位 は手指54例，手関節44例，时 13 例，足関節 9 例，肩 3 例，膝10例で小関節が多かった。薬物療法が併用された ものは 130 例あり， 3 例のみが併用なしであった。

\section{成 績}

(1) 総合評価

(1) 全般的有効性 
表 2 評価症例背景

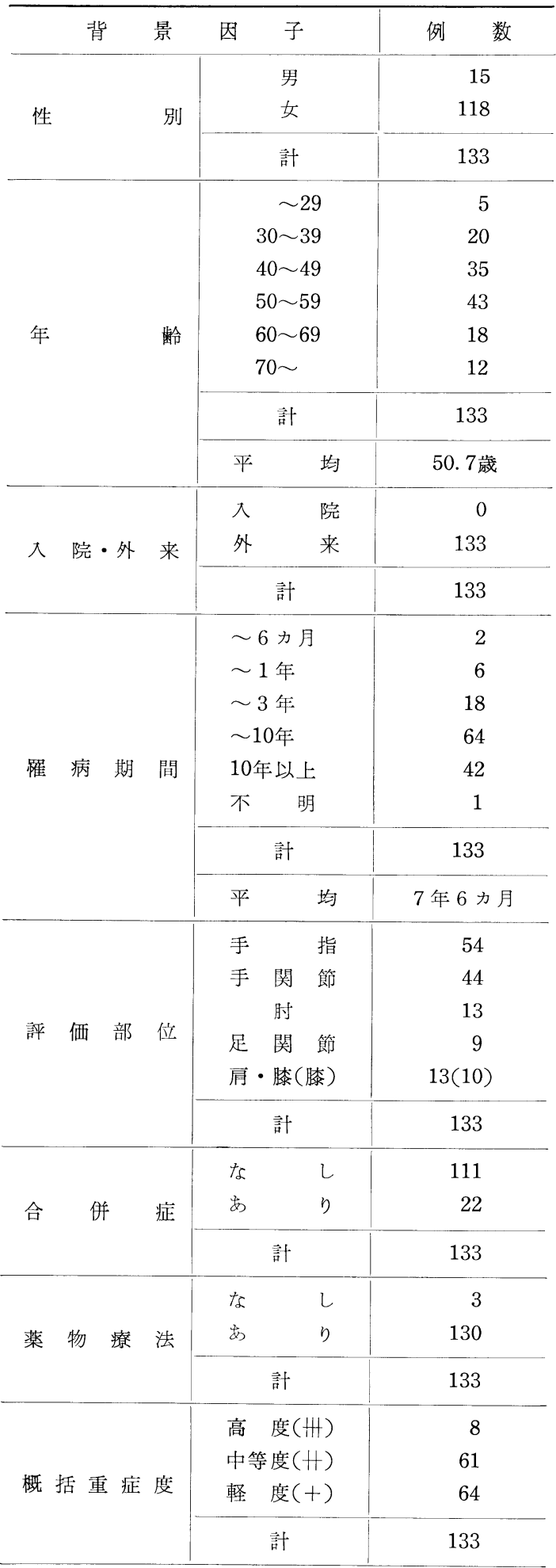

表 3 亿示すと扬り，著効 $5.3 \%$, 有効 $42.1 \%$ ，やや有 効 $21.1 \%$ であり，有效性（やや有効以上）は $68.4 \%$ で市 った.
表 3 全般的有効性

\begin{tabular}{r|r|r|r|r}
\hline 著 効 & 有 効 & やや有効 & 無 & $\begin{array}{r}\text { 有効 } \\
\left(\begin{array}{l}\text { や性 } \\
\text { 以上 } \%\end{array}\right.\end{array}$ \\
\hline 7 例 & 56 例 & 28 例 & 42 例 & $91 / 133$ \\
$5.3 \%$ & $42.1 \%$ & $21.1 \%$ & $31.6 \%$ & $(68.4 \%)$ \\
\hline
\end{tabular}

表 4 全般的安全性

\begin{tabular}{r|r|c|c|c|c}
\hline $\begin{array}{r}\text { 副作用 } \\
\text { な }\end{array}$ & $\begin{array}{c}\text { 軽度 } \\
\text { 副作用 }\end{array}$ & $\begin{array}{c}\text { 中等度 } \\
\text { 副作用 }\end{array}$ & $\begin{array}{c}\text { 高度 } \\
\text { 副作用 }\end{array}$ & 計 & $\begin{array}{c}\text { 副作用 } \\
(\%)\end{array}$ \\
\hline 127 例 & 6 例 & 0 & 0 & 133 例 & 6 例 \\
$95.4 \%$ & $4.6 \%$ & $0 \%$ & $0 \%$ & $100 \%$ & $4.6 \%$ \\
\hline
\end{tabular}

表 5 全般的有用性

\begin{tabular}{|c|c|c|c|c|}
\hline きわめて & \multirow{2}{*}{ 有 用 } & \multirow{2}{*}{ やや有用 } & \multirow{2}{*}{$\begin{array}{l}\text { 有用とは } \\
\text { 思われな } \\
\text { い }\end{array}$} & \multirow{2}{*}{ 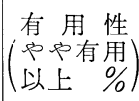 } \\
\hline 有 用 & & & & \\
\hline 12例 & 50例 & 34例 & 37例 & $96 / 133$ \\
\hline $9.0 \%$ & $37.6 \%$ & $25.6 \%$ & $27.8 \%$ & $(72.2 \%)$ \\
\hline
\end{tabular}

(2) 全般的安全性

表 4 亿示すと招り, 副作用は軽度副作用 $4.6 \%$ （6 例） のみであった。内訳は癌痒 3 例（うち投与中止 1 例), 発疹 2 例, 冷觉て具合が悪い 1 例（中止）であったが, すべて塗擦の局所的な皮䖉症状であり，重篤なものはな かった.

(3) 全般的有用性

表 5 飞示すと括り，きわめて有用 $9.0 \%$, 有用 $37.6 \%$, やや有用 $25.6 \%$ であり，有用性（やや有用以上）は72.2 \%であった。

（2）全般的有用性の項目別評価

(1) 概括重症度別評価

表 6 に示すと打り，重症度別の有用性は “やや有用” 以上\%は高度で $37.5 \%$, 中等度で $86.9 \%$, 軽度で $62.5 \%$ であり, 軽度, 中等度の有用性が高かった。

\section{(2) 部位別評価}

表 7 亿示すと扣り，部位別の有用性は“やや有用”以 上\%は手指 $79.6 \%$, 手関節 $77.3 \%$, 肘 $69.2 \%$, 足関節 $33.3 \%$, 肩, 膝 $53.8 \%$ で，小関節のほうがより有用性が 高かった。

\section{(3) 罹病期間別評価}

表 8 飞示すと打り，罹病期間別の有用性は“やや有用” 以上 $\%$ は 6 力月未満 $50.0 \% ， 1$ 年未満 $100 \% ， 3$ 年未満 $61.1 \%, 10$ 年未満 $65.6 \%, 10$ 年以上 $83.3 \%$ であり, 罹病 期間の長短にかかわらず有用であった。

(3) 改善度

(1) 患者の評価 
表 6 概括重泟度別評価

\begin{tabular}{|c|c|c|c|c|c|c|c|c|}
\hline 重 & 症 & 度 & きわめて有用 & 用 & やや有用 & $\begin{array}{l}\text { 有用とはな } \\
\text { 思われない }\end{array}$ & 計 & 有用率 $\left(\begin{array}{l}\text { やや有用 } \\
\text { 以上 } \%\end{array}\right)$ \\
\hline 高 & 度 & (HI) & 1 & 0 & 2 & 5 & 8 & $3 / 8 \quad(37.5 \%)$ \\
\hline 中 等 & 度 & $(H)$ & 6 & 30 & 17 & 8 & 61 & $53 / 61(86.9 \%)$ \\
\hline 軽 & 度 & $(+)$ & 6 & 20 & 15 & 24 & 64 & $40 / 64(62.5 \%)$ \\
\hline 合 & & 計 & 12例 & 50 例 & 34例 & 37例 & 133例 & $96 / 133(72.2 \%)$ \\
\hline
\end{tabular}

表 7 部位別評価

\begin{tabular}{|c|c|c|c|c|c|c|c|c|}
\hline \multicolumn{2}{|c|}{ 部 } & \multirow{2}{*}{ 位 } & \multirow{2}{*}{ 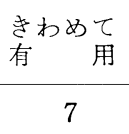 } & \multirow{2}{*}{$\frac{\text { 有 } \text { 用 }}{26}$} & \multirow{2}{*}{ やや有用 } & \multirow{2}{*}{$\begin{array}{c}\text { 有用とは } \\
\text { 思われない } \\
11\end{array}$} & \multirow{2}{*}{$\frac{\text { 計 }}{54}$} & \multirow{2}{*}{$\frac{\text { 有用率 }\left(\begin{array}{l}\text { やゃ有用 } \\
\text { 以上 }\end{array}\right)}{43 / 54(79.6 \%)}$} \\
\hline 手 & & & & & & & & \\
\hline 手 & 関 & 節 & 1 & 17 & 16 & 10 & 44 & $34 / 44(77.3 \%)$ \\
\hline & 时 & & 2 & 6 & 1 & 4 & 13 & $9 / 13(69.2 \%)$ \\
\hline 足 & 関 & 節 & 1 & 1 & 1 & 6 & 9 & $3 / 9 \quad(33.3 \%)$ \\
\hline 肩 & - 膝 & （膝） & $1(0)$ & $0(0)$ & $6(5)$ & $6(5)$ & $13(10)$ & $7 / 13(53.8 \%)$ \\
\hline & 計 & & 12例 & 50例 & 34例 & 37例 & 133例 & $96 / 133(72.2 \%)$ \\
\hline
\end{tabular}

表 8 嶊病期間別評価

\begin{tabular}{|c|c|c|c|c|c|c|c|}
\hline 罹 病 期 & 間 & $\begin{array}{l}\text { きわめて } \\
\text { 有 用 }\end{array}$ & 有 & やや有用 & $\begin{array}{l}\text { 有用とは } \\
\text { 思わなれい }\end{array}$ & 計 & 有用率 $\left(\begin{array}{l}\text { やや有用 } \\
\text { 以上 } \%\end{array}\right.$ \\
\hline$\sim 6$ 力月 & & 1 & 0 & 0 & 1 & 2 & $1 / 2 \quad(50.0 \%)$ \\
\hline$\sim 1$ 年 & & 3 & 1 & 2 & 0 & 6 & $6 / 6(100.0 \%)$ \\
\hline$\sim 3$ 年. & & 1 & 5 & 5 & 7 & 18 & $11 / 18(61.1 \%)$ \\
\hline ～ 10 年 & & 6 & 22 & 14 & 22 & 64 & $42 / 64(65.6 \%)$ \\
\hline 10年以上 & & 1 & 22 & 12 & 7 & 42 & $35 / 42(83.3 \%)$ \\
\hline 不 明 & & 0 & 0 & 1 & 0 & 1 & $1 / 1(100.0 \%)$ \\
\hline 計 & & 12例 & 50 例 & 34例 & 37例 & 133例 & $96 / 133(72.2 \%)$ \\
\hline
\end{tabular}

表 9 改善度一一患者の評価

\begin{tabular}{cc|c|c|c|c|c}
\hline & $\begin{array}{c}\text { 非常によくな } \\
\text { つた }\end{array}$ & よくなった & 変わらない & 悪くなった & 改善率 $\left.\begin{array}{c}\text { よくたょった } \\
\text { 以上 }\end{array}\right)$ \\
\hline 2 & 週 & 3 例 & 64 例 & 52 例 & 2 例 & $67 / 121(55.4 \%)$ \\
4 & 週 & 8 例 & 76 例 & 34 例 & 1 例 & $84 / 119(70.6 \%)$ \\
\hline
\end{tabular}

表 10 改善度一一医師の評価

\begin{tabular}{|c|c|c|c|c|c|c|c|c|}
\hline & & 著明改善 & 中等度改善 & 軽度改善 & 不 変 & 悪 & 改善率 & $\left(\begin{array}{ll}\text { 軽度改善 } \\
\text { 以上 }\end{array}\right)$ \\
\hline 2 & 週 & 3 例 & 21 例 & 48例 & 48例 & 1 例 & $72 / 121$ & $(59.5 \%)$ \\
\hline 4 & 週 & 7 例 & 40例 & 40 例 & 32例 & 0 例 & $87 / 119$ & $(73.1 \%)$ \\
\hline
\end{tabular}


表 11 症状別改善度

\begin{tabular}{|c|c|c|c|c|c|c|c|c|c|}
\hline 症 & & 状 & & 評価時期 & 改＼cjkstart善 & 変 & 悪 化 & 計 & 改善率 (\%) \\
\hline \multirow{2}{*}{ 自 } & \multirow{2}{*}{\multicolumn{2}{|c|}{ 発 }} & \multirow{2}{*}{ 痛 } & 2 週 & 15 & 70 & 0 & 85 & $15 / 85(17.6)$ \\
\hline & & & & 4 週 & 39 & 46 & 0 & 85 & $39 / 85(45.9)$ \\
\hline \multirow{2}{*}{ 圧 } & \multirow{2}{*}{\multicolumn{3}{|c|}{ 痛 }} & 2 週 & 22 & 97 & 0 & 119 & $22 / 119(18.5)$ \\
\hline & & & & 4 週 & 37 & 79 & 1 & 117 & $37 / 117(31.6)$ \\
\hline & \multirow{2}{*}{\multicolumn{2}{|c|}{ 動 }} & \multirow{2}{*}{ 痛 } & 2 週 & 22 & 98 & 0 & 120 & $22 / 120(18.3)$ \\
\hline & & & & 4 週 & 34 & 84 & 0 & 118 & $34 / 118(28.8)$ \\
\hline \multirow{2}{*}{ 局 } & \multirow{2}{*}{ 所 } & & \multirow{2}{*}{ 感 } & 2 週 & 13 & 44 & 0 & 57 & $13 / 57(22.8)$ \\
\hline & & 然 & & 4 週 & 17 & 36 & 0 & 53 & $17 / 53(32.1)$ \\
\hline \multirow{2}{*}{ 腫 } & & & \multirow{2}{*}{ 脹 } & 2 週 & 23 & 74 & 1 & 98 & $23 / 98(23.5)$ \\
\hline & & & & 4 週 & 46 & 52 & 0 & 98 & $46 / 98(46.9)$ \\
\hline \multirow{2}{*}{ 運 } & \multirow{2}{*}{\multicolumn{2}{|c|}{ 動 制 }} & \multirow{2}{*}{ 限 } & 2 週 & 9 & 92 & 0 & 101 & $9 / 101(8.9)$ \\
\hline & & & & 4 週 & 19 & 81 & 0 & 100 & $19 / 100(19.0)$ \\
\hline \multirow{2}{*}{\multicolumn{4}{|c|}{ 概 括 重 症 度 }} & 2 週 & 19 & 102 & 0 & 121 & $19 / 121(15.7)$ \\
\hline & & & & 4 週 & 40 & 79 & 0 & 119 & $40 / 119(33.6)$ \\
\hline
\end{tabular}

表 12 握力 $(\mathrm{mmHg})$

\begin{tabular}{|c|c|c|c|c|}
\hline 項 & 目 & 測定時期 & 例数 & $\mathrm{M} \pm \mathrm{SD}(\mathrm{mmHg})$ \\
\hline 握 & 力 & 投 与 前 & 91 & $132.3 \pm 55.6$ \\
\hline \multicolumn{5}{|c|}{ 検 } \\
\hline \multicolumn{2}{|c|}{ 検定項目 } & $\begin{array}{c}\text { 平均值の差 } \\
(\mathrm{mmHg})\end{array}$ & f & 值 \\
\hline \multicolumn{2}{|c|}{2 週一前 } & 6. 0 & 68 & $\mathrm{t}=2.95 \quad \mathrm{P}<0.01$ \\
\hline \multicolumn{2}{|c|}{4 週一前 } & 8.5 & 81 & $\mathrm{t}=5.00 \quad \mathrm{P}<0.001$ \\
\hline \multicolumn{2}{|c|}{4 週一 2 週 } & 3. 6 & 59 & $\mathrm{t}=2.10 \quad \mathrm{P}<0.05$ \\
\hline
\end{tabular}

表 9 に示すと拈り，2 週，4 週に打けるそれぞれの改 善度は“よくなった”以上は 2 週で $55.4 \%, 4$ 週で70. 6 \%であり， 2 週よりも 4 週で改善度が高かった。

(2) 医師の評価

表10に示すとおり，2週，4週に打けそれぞれの改 善度は “軽度改善” 以上は 2 週で $59.5 \%, 4$ 週で73. $1 \%$ であり，患者の評価と同様の傾向であった。

(3) 症状別改善度

表11に示すと拈り, 症状の改善率は 2 週, 4 週で各症 状別にみると, 自発痛 $17.6 \%, 45.9 \%$, 圧痛 $18.5 \%$, $31.6 \%$, 運動痛 $18.3 \%, 28.8 \%$, 局所熱感 $22.8 \%, 32.1$ $\%$, 腫脹 $23.5 \%, 46.9 \%$, 運動制限 $8.9 \%, 19.0 \%$, 概 括重症度 $15.7 \%, 33.6 \%$ であり，各症状とも 2 週より 4 週のほうが改善率が高かった。 また症状のなかでは自発 痛, 腫脹の改善率が注かに比べて高かった。
(4) 他覚所見
(1) 握力 $(\mathrm{mmHg})$

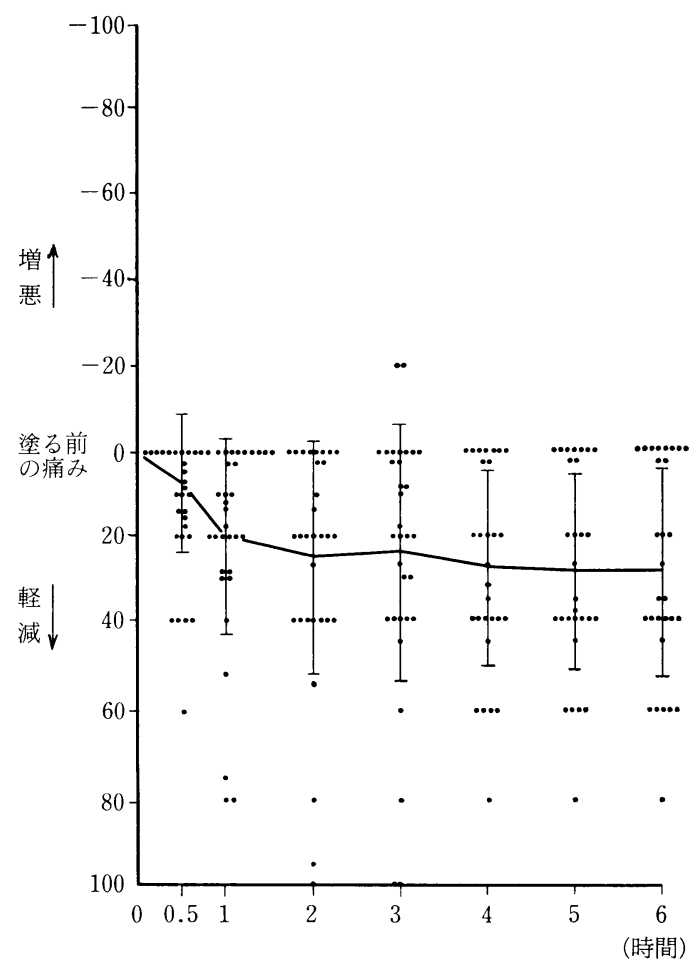

図 1 痛みの程度

局所の症状の変化に伴ら握力の変化について, 手指, 手関節の評価症例についてまとめると（表 12），投与前 の握力は $132.3 \pm 55.6 \mathrm{mmHg}($ mean $\pm \mathrm{SD})$ であり, 投 与前と 2 週および投与前と 4 週の差をみると, それぞれ $+6.0 \mathrm{mmHg},+8.5 \mathrm{mmHg}$ と改善がみられ, 有意に改 
表 13 痛多の程度

\begin{tabular}{|c|c|c|c|c|c|c|c|c|}
\hline 測定時期 & 例数 & 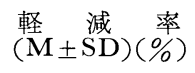 & \multirow[b]{3}{*}{ 検 } & 検定項目 & $\begin{array}{c}\text { 平均値の差 } \\
(\%)\end{array}$ & $\mathrm{f}$ & $\mathrm{t}$ & 値 \\
\hline 前 & 32 & - & & & & & & \\
\hline $0.5 \mathrm{hr}$ & 30 & $13.1 \pm 16.0$ & & $0.5 \mathrm{hr}$-前 & 13.1 & 29 & $\mathrm{t}=4.49$ & $\mathrm{P}<0.001$ \\
\hline $1 \mathrm{hr}$ & 32 & $20.0 \pm 23.2$ & \multirow{6}{*}{ 定 } & $1 \mathrm{hr}$-前 & 20.0 & 31 & $\mathrm{t}=4.88$ & $\mathrm{P}<0.001$ \\
\hline $2 \mathrm{hr}$ & 32 & $25.1 \pm 27.3$ & & $2 \mathrm{hr}$-前 & 25.1 & 31 & $\mathrm{t}=5.20$ & $\mathrm{P}<0.001$ \\
\hline $3 \mathrm{hr}$ & 32 & $23.7 \pm 29.8$ & & $3 \mathrm{hr}$-前 & 23.7 & 31 & $\mathrm{t}=4.51$ & $\mathrm{P}<0.001$ \\
\hline $4 \mathrm{hr}$ & 29 & $27.7 \pm 23.3$ & & $4 \mathrm{hr}$-前 & 27.7 & 28 & $\mathrm{t}=6.40$ & $\mathrm{P}<0.001$ \\
\hline $5 \mathrm{hr}$ & 29 & $28.6 \pm 23.4$ & & $5 \mathrm{hr}$-前 & 28.6 & 28 & $\mathrm{t}=6.58$ & $\mathrm{P}<0.001$ \\
\hline $6 \mathrm{hr}$ & 29 & $28.5 \pm 24.6$ & & $6 \mathrm{hr}$-前 & 28.5 & 28 & $\mathrm{t}=6.25$ & $\mathrm{P}<0.001$ \\
\hline
\end{tabular}

善（2 週: $\mathrm{P}<0.01,4$ 週 : $\mathrm{P}<0.001)$ 乙, さらに 2 週 よりも 4 週でさらに有意 $(\mathrm{P}<0.05)$ に改善している.

(2) 痛夕の程度

塗擦前を 0 として痛みの程度を軽減率 (\%) で示し, 10\%以上軽減している例を改善とすると（表 13 , 図 1), 改善率は塗擦30分で50\% (15/30), 1 時間で65.6\% (21/ 32), 2 時間で $65.6 \%$ (21/32)， 3 時間で $56.3 \%$ (18/ 32), 4 時間で69.0\% (20/29), 5 時間で69.0\% (20/29), 6 時間で65.5\%(19/29) となって拈り，塗擦30分から 6 時間まで50〜 70\%の症例に痛みの軽減がみられている。

（4）ID ゲル基剤との比較

ID ゲルと ID ゲル基剤を左右の概括重症度の同じ例 (手指あるいは手関節) に，一方に ID ゲル，他方に ID ゲル基剤を狳擦し，左右比較を行い得た症例は 5 例あっ たが，そのうち 1 例は ID ゲル, ID ゲル基剤いずれに おいても効果がないものであり，薬物に反応した 4 例の らち 3 例で ID ゲルのほらが全般的有効性, 全般的有用 性ともに優っていた.

\section{考 察}

非ステロイド性抗炎症剤インドメタシンは経口剂, 坐 剂として慢性関節リウマチに対して非常に有効で広く用 いられている。その反面, 全身投与に依存する副作用の 頭痛, 胃腸障害などが認められており, 投与方法に工夫 がなされている。

ID ゲルは局所適用により，消化管を経ず，インドメ タシンを十分薬効のある濃度で局所病変組織に到達させ るため，治療はより直接的であり，全身性の副作用はま ったく認められていない.

本剂はすでに運動器の局所的な炎症, 疼痛性疾患であ る変形性関節症 ${ }^{9)}$, 肩関節周囲炎 ${ }^{11)}$, 腱 - 腱鞘炎 ${ }^{15)}$, 腱

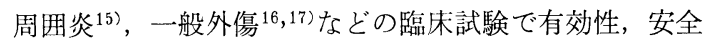
性および有用性が認められ，高く評価されている.

今回，われわれはすでにインドメタシンの経口剂拉よ び坐剂の有用性が確立されており, 広く用いられている 慢性関節リウマチに対して, その有効性が十分に期待さ
れ, さらに安全性の面でも心配がなく外用であるため使 用が軽便であるなど，一般療法と同様に薬物の基礎療法 としての有用性を期待してインドメタシンの外用剂であ るID ゲルの臨床試験を行った。

その結果, 全般的有効性は, やや有効以上 $68.4 \%$ と高 い有効性が得られた。全般的安全性は軽度副作用 6 例 (4.6\%)のみであり, 全般的有用性はやや有用以上で $72.2 \%$ と高い有用性が認められた。

全般的有用性について，概括重症度別にみると，“や や有用”以上 $\%$ は高度で $37.5 \%$, 中等度で $86.9 \%$, 軽度 で $62.5 \%$ であり, 中等度, 軽度の症例の有用性が高かっ た。また部位別にみると, “やや有用”以上\%は手指79.6 $\%$, 手関節 $77.3 \%$, 时 $69.2 \%$, 足関節 $33.3 \%$, 肩, 膝 $53.8 \%$ で，小関節である手指だけでなく比較的小関節で ある手関節，肘に括いても高い有用性が認められた。こ れは小関節の汪らが関節組織への浸透が容易であるもの と考えられ，また本剤の鎮痛作用が末梢性に発揮される こととも関係していると思われる。

罹病期間別では有用性に一定の関係がなく，罹病期間 の短い症例でも長い症例でも同程度に有用性が期待でき る.

改善度について, 患者の評価は 2 週よりも 4 週で改善 度が $55.4 \%$ から70.6\%(“よくなった以上”) と高くなっ ているが，これは ID ゲルの使用回数の増加に伴い組織 内濃度が一定になり安定した効果が出現するためと思わ れる。医師の評価においても同様な結果が得られてい る.

また症状別改善度においても 2 週よりも 4 週の改善率 が高く，特に白発痛と腫脹では $45 \%$ 以上と改善率が高か った。

つぎに他覚所見については, 握力の測定と visual analogue scale による痛みの程度を検討した，握力は手指， 手関節の評価症例のみで，2週，4週と改善がみられ， 2 週よりも 4 週でさらに改善している.これは痛みの改 善, 腫脹の改善がそのまま握力の改善となってあらわれ たものと思われる. 
一方，痛みの程度を visual analogue scale で評価し， 改善率をみると, 初回塗擦前と比べると, 叙擦30分で50 $\%$ ，1 時間で65.6\%，2 時間で65.6\%，3 時間で56.3\%， 4 時間で $69.0 \% ， 5$ 時間で $69.0 \% ， 6$ 時間で $65.5 \%$ であ り, 塗擦30 分といら早期より $50 \%$ に痛及の改善がみら れ, また塗擦 6 時間でも65.6\%が改善しており, 全体的 にみて, 効果の発現が早く, かなりの持続効果がある.

つぎに, ごく一部の症例で ID ゲルと ID ゲル基剤の 左右比較を行ったところ, 薬物に反応した 4 例のらち 3 例で ID ゲルの全般的有効性, 有用性とも優り, ID ゲ ルの ID ゲル基剤に対する効果の有意性が推察される。

副作用については，軽度副作用 6 例 (4.6\%) のみであ り, 内訳㥽痒 3 例, 発疹 2 例, 冷えて具合が悪い（塗 擦部位） 1 例であり，すべて塗擦の局所的な皮膚症状で あり,インドメタシン経口投与, 坐剤投与時にみられる 胃腸障害, 頭痛などの全身性の副作用はまったく認めら れなかった。またその発現率も $4.6 \%$ と低く, 重篤な副 作用もなく, 安全性が高いと考学られる。臨床検査に拉 いても, 血液一般検査, 血清生化学検查, 尿検査におい て臨床的に考慮すべき動きはなかった。

以上より ID ゲルの慢性関節りウマチの治療体系への 位置つけを考えてみると, 全般的有効性は $68.4 \%$ と高い 有効性が得られ, 安全性の面でも心配がなく, 外用であ るため使用が軽便であるなど，一般療法同様に薬物の基 礎療法として非常に広く, 大多数に用いられる薬剤であ ることがわかった。

\section{まとめ}

ID ゲルの慢性関節リウマチに対する有用性を検討す る目的で小関節を中心に 133 例に一般臨床試験を多施設 共同で行い，一部症例に ID ゲル基剂との左右比較試験 を行った。

(1) 全般的有効性に扣いて，やや有効以上は $68.4 \%$ (91/133) と高い有效性が認められた.

(2) 全般的安全性に拈いて，副作用は 4.6\% (6/133) で, 瘙痒, 発疹, 冷えて具合が悪い, ですべて塗擦によ る局所的な軽度副作用であった。 また臨床検査值にも異 常がみられず, 本剂の高い安全性が示された。

(3) 全般的有用性に打いて, やや有用以上は $72.2 \%$ と 高い有用性が認められた。

(4) 概括重症度別の有用性では, 軽度, 中等度の有用 性が高く, 部位別では, 手指のみならず手関節, 肘に拉 いても高い有用性が認められた。

(5)改善度は患者の評価, 医師の評価とも2 週よりも 4 週のほらが高い改善を示した。 症状別では, 自発痛と 腫脹の改善率が高かった。

(6) 握力に拈いて, 手指, 手関節で有意な改善がみら れた。
(7) 痛みの visual analogue scale による評価では痛 みは30分くらいから50\% (15/30) 改善し， 6 時間でも $65.5 \%(19 / 29)$ とかなり持続効果があった。

(8) ID ゲルの ID ゲル基剤に対する左右比較におい ては，ID ゲルの効果の有意性が推察された.

以上より，ID ゲルは慢性関節リウマチに対して，有 効性, 安全性, 有用性の面より, 一般療法同様に薬物の 基礎療法として, 非常に広く, 大多数の症例に用いられ る薬剤であることがわかった。

\section{文 献}

1) 塩川優一：慢性関節リウマチの薬物療法の現 況 (アンケート調查成績). リウマチ 13(3):303-314, 1973.

2) 水島 裕：慢性関節リウマチ扣よび他の膠原病の 楽物療法の現状.リウマチ 18(5):325-334, 1978.

3）輿石義晴：わが国に打ける慢性関節りウマチの薬 物療法の現状（アンケート調査成績），治療 62 (3): 627-639, 1980.

4) 木全秀樹, 松本 修, 小出高志, 稲木敏男, 石浜 洋：インドメタシンの経皮吸収——第 1 報。薬理 と治療 7 (Suppl. 1)：21-27, 1979.

5) 木全秀樹, 松本 修, 小出高志, 稲木敏男, 石浜 洋：インドメタシンの経皮吸収一一第 2 報。薬理 と治療 7 (Suppl. 1)：29-33，1979.

6) 犬飼利也, 栗田弘, 黒川寛, 安達路子, 仲西 淑子, 永尾泰子：インドメタシン軟高の消炎, 鎮 痛作用。薬理と治療 7 (Suppl. 1)：3-13, 1979.

7) 和田靖史, 江藤義則, 大平明良, 木全秀樹, 小出 高志, 石浜 洋, 水島 裕: インドメタシン外用 製剂の局所的抗炎症作用扣よび経皮吸収。炎症 1(4): 511-514, 1981.

8）長谷川頼彦, 山本純已, 児玉俊夫, 佐伯清美 : イ ンドメタシン軟亳のラットに颃ける局所抗炎症作 用. 薬理と治療 7 (Suppl. 1)：15-19, 1979.

9）景山孝正, 工藤 洋, 岩野邦男, 並木 脩, 豊島 弘道，仁科交男，菅原幸子，石上宮子，大井淑 雄, 青木虎吉, 吉崎克文, 阿部光俊, 興津勝彦, 上山秀隆, 長谷川攻, 星野 孝, 宮地直恒, 東 博彦, 正田達夫, 山本 真, 田場弘之, 河路 渡, 望月一男，黑木良克，鈴木勝己，佐藤 茂，菅野 卓郎, 白野 明, 三谷晋一, 高田 聡, 大坪 良, 村田 久, 野村利夫, 川村次郎, 高橋 洋, 陳 永振, 田中恒男: 変形性関節症に対するインドィ タシン軟高の有用性検討. 㭗理と治療 7 (Suppl. 1): 197-215, 1979.

10）宮永豊, 阿部 績, 東 晃, 園崎秀吉, 松浦美 喜雄, 望月直哉: 整形外科領域に打けるインドメ タシン軟膏の臨床成績. 薬理と治療 7(Suppl. 1): 119-134, 1979.

11）村瀬鎮雄, 唐沢重雄, 宮島昭博, 下小野田瞱夫 : インドメタシン軟亮の臨床経験。薬理と治療 7 (Suppl. 1): 109-118, 1979.

12）根岸雅夫：インドィタシン軟膏（イドィシンュー ワダル）の膠原病に対する使用経験。薬理と治療 9(4): 1531-1534, 1981.

13）肥後 勝, 前原東洋：慢性関節リウマチと変形性 
膝関節症に対するインドィタシンゲル剤 (ID ゲ ル）の臨床経験。薬理と治療 9(7)：2877-2882, 1981.

14）吉岡 薰, 日下 治, 村上恒二, 渡 捷二 : 整形 外科領域に拈けるインドメタシンゲル剤 (ID ゲ ル）の臨床使用経験. 薬理と治療 9(7)：28832895, 1981.

15）津山直一, 七川歓次, 辻本正記, 宮永 豊, 水島 裕, 中島章: 整形外科領域に打兴非ステロイ ド性外用消炎; 鎮痛剂——ンドメタシン軟高 一の臨床評価。臨床評価 7(2)：285-309, 1979.
16）伊勢舶副士朗, 花岡英弥, 宇沢充吉, 村上隆一, 戸松泰介, 宮本銈造, 浜野恭之, 末安 誠, 岩田 清二, 稲垣壮太郎, 村田 光, 細谷俊彦, 中西忠 行, 松 賢次郎, 中島 章, 水島 裕: 一般外傷 （打撲，挫傷，捻挫）に対するインドメタシン軟 膏の臨床評価。臨床評価 7(2)：265-284， 1979.

17) 岩田久, 揖野學而：外用非ステロイド性抗炎 症 ; 鎮痛剤インドメタシン軟高の外傷に対する二 重盲検試験。薬理と治療 7(Suppl. 1)：245-254, 1979. 